\title{
Relationship between hand grip strength and nutritional assessment methods used of hospitalized patients
}

\author{
Relação entre a força do aperto da mão \\ e métodos de avaliação nutricional \\ em pacientes hospitalizados ${ }^{1}$
}

\author{
Monique Ferreira GARCIA² \\ Marion Schneider MEIRELES 2 \\ Letícia Maria FÜHR² \\ Amanda Brognoli DONINI ${ }^{3}$ \\ Elisabeth WAZLAWIK²
}

\section{(f}

ORIGINAL | ORIGINAL

- 
50 | MF GARCIA et al.

Malnourished individuals according to body mass index had, on average, 11.0kg less hand grip strength than the nourished individuals $(p=0.008)$. There was no association between hand grip strength and the subjective global assessment (malnourished individuals had -2.8kg; $p=0.078$ ) and nutritional risk screening 2002 (malnourished individuals had $-1.5 \mathrm{~kg} ; p=0.352$ ).

\section{Conclusion}

Hand grip strength was associated with body mass index but not with the subjective global assessment or nutritional risk screening 2002.

Indexing terms: Nutritional assessment. Nutritional status. Hand strength. Body mass index. Inpatients.

\section{R E S U M O}

\section{Objetivo}

Verificar a associação da força do aperto da mão com o índice de massa corporal, a avaliação subjetiva global e o rastreamento de risco nutricional 2002.

\section{Métodos}

Estudo transversal com 118 pacientes internados no Hospital Universitário da Universidade Federal de Santa Catarina, Florianópolis, Brasil. Foi calculado o índice de massa corporal e foram aplicados a avaliação subjetiva global, o rastreamento de risco nutricional 2002 e a força do aperto da mão. Esta última foi comparada aos valores de referência da população brasileira, segundo sexo e idade. Para análise estatística, foi utilizado o teste t Student ou Mann-Whitney e regressão linear múltipla, considerando uma significância estatística de $p<0,05$.

\section{Resultados}

A prevalência de risco nutricional ou desnutrição pelo índice de massa corporal, avaliação subjetiva global, rastreamento de risco nutricional 2002 e força do aperto da mão foi de 3,5\%, 50,9\%, 33,9\% e 35,6\%, respectivamente. Os indivíduos, identificados como desnutridos pelo índice de massa corporal, tiveram, em média, $11,0 \mathrm{~kg}$ a menos na força do aperto da mão do que os nutridos $(p=0,008)$. Não houve associação da força do aperto da mão com a avaliação subjetiva global (desnutridos tiveram -2,8kg; $p=0,078$ ) e com o rastreamento de risco nutricional 2002 (desnutridos tiveram -1,5kg; $p=0,352$ ).

\section{Conclusão}

A força do aperto da mão foi associada com o índice de massa corporal, mas não com avaliação subjetiva global ou com o rastreamento de risco nutricional 2002.

Termos de indexação: Avaliação nutricional. Estado nutricional. Força da mão. Índice de massa corporal. Pacientes internados.

\section{NTROD UCTION}

An ideal method for assessing the nutritional status of patients should include dietary intake, nutritional requirements, functional status and body composition ${ }^{1}$. However, in the absence of a gold standard, scientists tried to identify new methods capable of accurately diagnosing malnutrition ${ }^{2-4}$. Many tools have been used; however, their validity is still controversial ${ }^{5}$.

In clinical practice and in the hospital setting, Body Mass Index (BMI) ${ }^{6}$, Subjective Global Assessment (SGA) ${ }^{7}$ and Nutritional Risk Screening
2002 (NRS 2002) ${ }^{8}$ are frequently used while Hand Grip Strength (HGS) is often reported as an indicator of functional capacity ${ }^{9}$.

Body Mass Index indirectly assesses nutritional status and depends on weight and height. It is a simple index and an easy-to-use method, commonly used for classifying malnutrition, overweight and obesity ${ }^{6}$.

The Subjective Global Assessment is a clinical nutritional assessment method developed by Detsky et al. ${ }^{7}$. It investigates clinical history and includes a subjective physical examination. It is 
considered a simple, inexpensive and easy-to-use technique, and provides important nutritional information².

The Nutritional Risk Screening 2002 is used for determining the risk of malnutrition by assessing the severity of the disease, BMI, percentage of weight loss and food intake. Hence, malnutrition and/or severe disease may indicate the need of nutritional support ${ }^{8}$.

Hand Grip Strength is determined by dynamometry. It is a noninvasive, simple and quick method that can be used in clinical and epidemiological studies ${ }^{10,11}$. It may be useful for the assessment of nutritional status ${ }^{11-13}$, since malnourished patients present lean mass depletion and low muscle strength ${ }^{10,11}$.

Given the importance of scientific evidence proving the efficiency of HGS for assessing nutritional status, the objective of this study was to verify its association with BMI, SGA and NRS 2002 in hospitalized patients.

\section{METHODS}

This is a cross-sectional study of patients aged $\geq 19$ years of the University Hospital of the Universidade Federal de Santa Catarina (HU/UFSC) hospitalized between July 2010 and July 2011 . Patients unable to understand instructions and communicate, pregnant or breastfeeding women and those with amputated or atrophied limbs were excluded.

The project was approved by the UFSC Human Research Ethics Committee under protocol $n^{\circ} 333 / 08$, and all participants signed an informed consent form before the interview and assessment of their nutritional status.

The patients' clinical data were obtained from their hospital records. All nutritional status assessments were done on the same occasion. The researchers were previously trained for ensuring the reliability of the nutritional status assessment and data collection.

\section{Hand grip strength}

Hand grip strength was measured using a hydraulic hand dynamometer Saehan ${ }^{\circledR}$ model SH 5001 (Saehan Corporation - Yangdeok-Dong, Masan, Korea) with a capacity of $90 \mathrm{~kg}$.

The evaluation was done with the patient seated, with hips and knees at $90^{\circ}$ of flexion, adducted shoulder close to the trunk, flexed elbow at $90^{\circ}$ with the forearm in neutral position (between pronation and supination) and wrist between $0^{\circ}$ and $30^{\circ}$ of extension and $0^{\circ}$ and $15^{\circ}$ of ulnar deviation ${ }^{12}$.

A pretest was done allowing the participant to become familiar with the apparatus. The researcher verbally instructed the participant to exert maximum palmar prehension three times and the highest value was used ${ }^{12}$. HGS was evaluated on the arm side without vascular access. The results were compared with the reference values for the Brazilian population ${ }^{11}$ and the patients were classified as malnourished when their HGS was below the tenth percentile ${ }^{11}$.

\section{Body mass index}

Weight $(\mathrm{kg})$ and height $(\mathrm{m})$ were determined as recommended by the World Health Organization ${ }^{14}$. BMI was calculated by dividing the weight by the square of the height. Patients were classified as malnourished ${ }^{6}$ when $\mathrm{BMl}<18.5 \mathrm{~kg} / \mathrm{m}^{2}$, normal weight when $18.5 \mathrm{~kg} / \mathrm{m}^{2} \leq \mathrm{BMI} \leq 24.9 \mathrm{~kg} / \mathrm{m}^{2}$, overweight when $25.0 \mathrm{~kg} / \mathrm{m}^{2} \leq \mathrm{BMI} \leq 29.9 \mathrm{~kg} / \mathrm{m}^{2}$ and obese when $\mathrm{BMl} \geq 30 \mathrm{~kg} / \mathrm{m}^{2}$. For the statistical analysis, the patients were classified as malnourished $\left(\mathrm{BMl}<18.5 \mathrm{~kg} / \mathrm{m}^{2}\right)$ or nourished $\left(B M I \geq 18.5 \mathrm{~kg} / \mathrm{m}^{2}\right)$.

Weight and height were measured using an electronic scale with stadiometer (Welmy, W300, Santa Bárbara D'Oeste, São Paulo, Brazil).

\section{Subjective global assessment}

The Subjective Global Assessment was done as recommended by Detsky et al. ${ }^{7}$, considering weight loss history, changes in food 
intake, gastrointestinal symptoms, functional capacity, metabolic stress and physical examination. The patients were classified as $A$ (nourished); $\mathrm{B}$ (moderately or possibly malnourished); and $C$ (severely malnourished). For the statistical analysis, the categories $\mathrm{B}$ and $\mathrm{C}$ were grouped.

\section{Nutritional Risk Screening 2002}

The Nutritional Risk Screening 2002 was performed as recommended by Kondrup et al. ${ }^{8}$ Nutritional risk was determined by two components: impaired nutritional status (BMI, weight loss, food intake) and disease severity. The following scores were given for nutritional status and disease severity: 0 - absent; 1 - mild; 2 - moderate; and 3 - severe. Patients with a total score of 3 or more were considered at nutritional risk, and patients aged $\geq 70$ years received an extra point in the total score ${ }^{8}$.

\section{Statistical analysis}

The results were expressed as relative and absolute frequencies, mean and $95 \%$ confidence interval.
The Chi-square or Fisher's exact test was used for analyzing the association between the categorical variables and the Student's $t$-test or Mann-Whitney test for verifying the differences between the means of the groups, depending on the homogeneity of the variances, since the outcome variable was symmetrical. Multiple linear regression adjusted for age and gender was used for verifying the association between HGS and the other nutritional indicators. $P$-values $<0.05$ were considered statistically significant. All analyses were done by the software Stata, version 11.0 for Windows (Stata Corporation, College Station, TX, USA).

\section{RES U LT S}

The sample consisted of 118 patients with a mean age of $50.4 \pm 15.0$ years (19 to 85 years). Most were females $(72.0 \%)$ aged $<60$ years (71.7\%). The most common diagnoses were cancer $(11.9 \%)$, pulmonary diseases $(11.6 \%)$, heart disease $(10.2 \%)$ and liver disease $(7.6 \%)$. Two-thirds $(66.1 \%)$ of the sample had some comorbidity (men $=34.4 \%$ and women $=76.6 \%$;

Table 1. Prevalence of malnutrition according to Hand Grip Strength (HGS), Body Mass Index (BMI), Subjective Global Assessment (SGA) and Nutritional Risk Screening 2002 (NRS 2002) by gender. Florianópolis (SC), Brazil, 2011.

\begin{tabular}{|c|c|c|c|c|c|c|c|}
\hline \multirow{2}{*}{ Method } & \multicolumn{2}{|c|}{ Total } & \multicolumn{2}{|c|}{ Men } & \multicolumn{2}{|c|}{ Women } & \multirow{2}{*}{$p$-value* } \\
\hline & $\mathrm{n}$ & $\%$ & $n$ & $\%$ & $n$ & $\%$ & \\
\hline HGS & & & & & & & 0.242 \\
\hline$\leq p 10$ & 42 & (35.6) & 9 & (27.3) & 33 & (38.8) & \\
\hline$>p 10$ & 76 & (64.4) & 24 & (72.7) & 52 & $(61.2)$ & \\
\hline$B M l$ & & & & & & & 0.571 \\
\hline$<18.5 \mathrm{~kg} / \mathrm{m}^{2}$ & 4 & (3.5) & 0 & $(0.0)$ & 4 & (4.8) & \\
\hline$\geq 18.5 \mathrm{~kg} / \mathrm{m}^{2}$ & 112 & (96.5) & 32 & (100.0) & 80 & (95.2) & \\
\hline$S G A$ & & & & & & & 0.084 \\
\hline$B+C$ & 60 & (50.9) & 21 & (63.6) & 39 & (45.9) & \\
\hline A & 58 & (49.1) & 12 & (36.4) & 46 & (54.1) & \\
\hline NRS 2002 & & & & & & & 0.612 \\
\hline$\geq 3$ & 40 & (33.9) & 10 & (30.3) & 30 & (35.3) & \\
\hline$<3$ & 78 & (66.1) & 23 & (69.7) & 55 & $(64.7)$ & \\
\hline
\end{tabular}

${ }^{*}$ Chi-square or Fisher's exact test for the association between genders.

$\mathrm{BMI}<18.5$ : malnourished; $\mathrm{BMI} \geq 18.5$ : nourished/overweight/obese; SGA B+C: malnourished; ASG A: well nourished; NRS 2002 $\geq 3$ : at nutritional risk; NRS $2002<3$ : not at nutritional risk; HGS $\leq$ 10: malnourished; HGS >p10: nourished 
$p<0.001)$, and of these, $20.3 \%$ had Diabetes Mellitus (DM) and 39.8\% had High Blood Pressure (HBP). HBP was significantly more common in women.

Table 1 shows the classification of the nutritional status of the patients according to gender. According to HGS, BMI, SGA and NRS $2002,35.6 \%, 3.5 \%, 50.9 \%$ and $33.9 \%$, respectively were at nutritional risk or malnourished. The prevalences of malnutrition of men and women did not differ.

The mean HGS of the sample was $25.0 \pm 11.6 \mathrm{~kg}$, and that of the women $(20.2 \pm 6.6$ $\mathrm{kg}$ ) was significantly lower than that of the men (37.3 $\pm 12.6 \mathrm{~kg} ; p<0.001)$. HGS was significantly lower in patients aged $\geq 60$ years, in those with some comorbidity (Table 2) and in malnourished patients according to BMI (Table 3).

After adjusting for age and gender, the mean HGS of malnourished patients according to BMI was $11 \mathrm{~kg}$ lower than that of nourished patients. Among those malnourished according to the SGA, the mean HGS was $2.8 \mathrm{~kg}$ lower than that of the nourished. Among those at nutritional risk according to the NRS 2002, the mean HGS was $1.5 \mathrm{~kg}$ lower than that of the nourished.

Table 2. Relationship between Hand Grip Strength (HGS) and age, presence of comorbidities, diabetes mellitus and High Blood Pressure (HBP) by gender. Florianópolis (SC), Brazil, 2011.

\begin{tabular}{|c|c|c|c|c|c|c|}
\hline Methods & HGS Total & $p^{*}$ & $\mathrm{HGS}^{\mathrm{a}}$ Men & $p^{*}$ & HGS ${ }^{a}$ Women & $p^{\dagger}$ \\
\hline Age (years) & & 0.004 & & 0.004 & & 0.012 \\
\hline$<60$ & $26.8(24.2 ; 29.5)$ & & $41.1(36.2 ; 45.9)$ & & $21.3(19.6 ; 23.1)$ & \\
\hline$\geq 60$ & $20.1(17.3 ; 22.9)$ & & $27.4(19.9 ; 34.9)$ & & $17.3(15.3 ; 19.3)$ & \\
\hline Presence of comorbidity & & 0.001 & & 0.729 & & 0.258 \\
\hline No & $29.8(25.5 ; 34.2)$ & & $36.4(29.9 ; 42.8)$ & & $21.7(18.4 ; 24.9)$ & \\
\hline Yes & $22.5(20.4 ; 24.7)$ & & $37.9(31.5 ; 44.5)$ & & $19.8(18.2 ; 21.4)$ & \\
\hline Diabetes Mellitus & & 0.799 & & 0.698 & & 0.682 \\
\hline No & $25.2(22.7 ; 27.6)$ & & $37.8(32.6 ; 42.9)$ & & $20.1(18.4 ; 21.8)$ & \\
\hline Yes & $24.5(20.4 ; 28.5)$ & & $35.5(23.2 ; 47.8)$ & & $20.1(18.2 ; 23.5)$ & \\
\hline $\mathrm{HBP}$ & & 0.348 & & 0.932 & & 0.849 \\
\hline No & $26.1(23.1 ; 29.2)$ & & $37.7(31.7 ; 43.7)$ & & $20.1(17.9 ; 22.2)$ & \\
\hline Yes & $23.3(20.7 ; 25.9)$ & & $37.2(31.5 ; 43.0)$ & & $20.4(18.5 ; 22.3)$ & \\
\hline
\end{tabular}

aMean and 95\% confidence interval. *Student's t-test or Mann-Whitney test.

Table 3. Mean Hand Grip Strength (HGS) according to Body Mass Index (BMI), Subjective Global Assessment (SGA) and Nutritional Risk Screening 2002 (NRS 2002) by gender. Florianópolis (SC), Brazil, 2011.

\begin{tabular}{|c|c|c|c|c|c|c|}
\hline Methods & HGS $^{\mathbf{a}}$ Total & $p^{*}$ & $\mathrm{HGS}^{\mathrm{a}}$ Men & $p^{*}$ & $\mathrm{HGS}^{\mathrm{a}}$ Women & $p^{*}$ \\
\hline$B M I$ & & 0,003 & & - & & 0.004 \\
\hline$<18.5 \mathrm{~kg} / \mathrm{m}^{2}$ & $11.3(7.7 ; 14.8)$ & & - & & $11.3(7.7 ; 14.8)$ & \\
\hline$\geq 18.5 \mathrm{~kg} / \mathrm{m}^{2}$ & $25.4(23.3 ; 27.5)$ & & - & & $20.8(19.3 ; 22.2)$ & \\
\hline SGA & & 0.440 & & 0.070 & & 0.054 \\
\hline$B+C$ & $24.2(21.3 ; 27.1)$ & & $34.4(29.6 ; 39.1)$ & & $18.7(16.5 ; 20.9)$ & \\
\hline A & $25.9(22.7 ; 29.0)$ & & $42.6(33.2 ; 51.9)$ & & $21.5(19.7 ; 23.3)$ & \\
\hline NRS 2002 & & 0.095 & & 0.322 & & 0.117 \\
\hline$\geq 3$ & $22.5(19.2 ; 25.7)$ & & $34.0(26.3 ; 41.7)$ & & $18.7(16.1 ; 21.4)$ & \\
\hline$<3$ & $26.3(23.6 ; 29.0)$ & & $38.8(33.1 ; 44.6)$ & & $21.1(19.4 ; 22.7)$ & \\
\hline
\end{tabular}

aMean and 95\% confidence interval. "Student's t-test or Mann-Whitney test. 
54 | MF GARCIA et al

Table 4. Multiple linear regression of hand grip strength and nutritional indicators. Florianópolis (SC), Brazil, 2011.

\begin{tabular}{|c|c|c|c|c|c|c|}
\hline & \multicolumn{3}{|c|}{ Crude } & \multicolumn{3}{|c|}{ Adjusted ${ }^{*}$} \\
\hline & Beta & $95 \% \mathrm{Cl}$ & $p$-value & Beta & $95 \% \mathrm{Cl}$ & $p$-value \\
\hline$B M I$ & & & 0.014 & & & 0.008 \\
\hline$\geq 18.5 \mathrm{~kg} / \mathrm{m}^{2}$ & 0.0 & - & & 0.0 & - & \\
\hline$<18.5 \mathrm{~kg} / \mathrm{m}^{2}$ & -14.2 & $(-25.5 ;-2.9)$ & & -11.0 & $(-19.1 ;-2.9)$ & \\
\hline SGA & & & 0.440 & & & 0.078 \\
\hline$A$ & 0.0 & - & & 0.0 & - & \\
\hline$B+C$ & -1.7 & $(-5.9 ; 2.6)$ & & -2.8 & $(-5.9 ; 0.3)$ & \\
\hline NRS 2002 & & & 0.095 & & & 0.352 \\
\hline$<3$ & 0.0 & - & & 0.0 & - & \\
\hline$\geq 3$ & -3.8 & $(-8.2 ; 0.7)$ & & -1.5 & $(-4.8 ; 1.7)$ & \\
\hline
\end{tabular}

${ }^{*}$ Adjusted for age and gender.

BMI: Body Mass Index; SGA: Subjective Global Assessment; NRS 2002: Nutritional Risk Screening 2002.

However, the difference between the mean HGS of nourished and malnourished patients according to the SGA and NRS 2002 was not significant, even after adjustment (Table 4).

\section{DISCUSSION}

The relationship between HGS and BMI, SGA and NRS 2002 was investigated to verify its use for the diagnosis of malnutrition. Malnourished patients or those at risk of malnutrition should be identified at hospital admission to receive nutritional support, reduce their nutritional deficiencies and contribute to the improvement of their clinical prognosis 3 ,15,16.

Body cell mass may decrease in malnourished patients, leading to functional loss. Therefore, it is important to use a technique capable of assessing functional capacity ${ }^{17}$ and detecting malnutrition early ${ }^{18}$.

Hand grip strength is a method that assesses muscle strength and functional capacity ${ }^{11,19}$. It has been described as an appropriate tool for the nutritional screening and diagnosis of healthy populations ${ }^{11,12}$ and hospitalized individuals ${ }^{17}$.

The prevalence of malnutrition in the present study varied from $3.5 \%$ to $50.9 \%$, confirming that the assessment method may affect nutritional diagnosis ${ }^{20}$. The low prevalence of malnutrition according to $\mathrm{BMI}$ corroborated other studies ${ }^{21,22}$. On the other hand, the prevalence of malnutrition according to the SGA $(50.9 \%)$ was higher than that reported by other studies $(22.0 \%, 28.0 \%, 18.7 \% \text { and } 29.6 \%)^{21,23-25}$. Likewise, the classification of nutritional risk according to the NRS 2002 (33.9\%) was also higher than that reported by other studies $(20.0 \%$ and $27.5 \%)^{21,25}$.

The different prevalences of malnutrition in the present study may be attributed to the specificities of each method, which can assess distinct characteristics. BMI considers only the relationship between weight and height ${ }^{6}$. Meanwhile, the SGA and NRS 2002 investigate aspects associated with weight loss, food intake and disease-related stress. Furthermore, the SGA also takes into account gastrointestinal symptoms, functional capacity and physical examination, and the NRS 2002 considers $\mathrm{BMI}^{7,8}$. Finally, HGS estimates muscle strength by determining the prehension force that an individual exerts on the dynamometer ${ }^{11}$.

The higher prevalence of malnutrition according to the SGA compared with other studies of patients with similar ages may stem from the smaller impact of the latter's diagnoses on nutritional status. 
Cut-off points for the determination of malnutrition according to HGS are scarce. The present study used the reference values for the Brazilian population proposed by Schlüssel et al. ${ }^{11}$. The prevalence of malnutrition according to HGS was low $(38.1 \%)$ when compared with other studies that found a prevalence of $73.3 \%$ in patients with Crohn's disease ${ }^{24}$ and $63 \%$ in patients with cyrrhosis ${ }^{23}$. One of the justifications is the different cut-off points used and, possibly, disease severity.

The presence of malnutrition did not differ between the genders. However, in other studies, men were more often malnourished according to $\mathrm{HGS}^{24}$ and SGA ${ }^{17,26}$. In the present study, none of the men was malnourished according to BMI.

The prevalence of malnutrition according to HGS was greater than that according to BMI. A similar result was obtained by Gottschall et al. ${ }^{10}$ for patients with cirrhosis; they found that HGS was more sensitive for the detection of malnutrition than BMI. This probably occurred because BMI does not distinguish between lean and fat mass ${ }^{6}$. Hence, an individual may often seem to have an appropriate nutritional status (BMl>18.5 kg/ $/ \mathrm{m}^{2}$ ) but have low lean body mass ${ }^{27}$, which can be directly verified by HGS ${ }^{11}$. Moreover, some diseases, such as liver cirrhosis and pulmonary diseases, may cause hydration changes, and consequently affect BMI 10,14,22.

The hand grip strength of men was significantly higher than that of women, as was those of patients aged $<60$ years compared with older patients, which is in agreement with Brazilian studies of healthy ${ }^{11}$ and hospitalized individuals ${ }^{28,29}$.

Álvares-da-Silva \& Silveira ${ }^{23}$ showed that HGS was capable of predicting clinical complications, which may explain the lower HGS of individuals with comorbidities in the present study. In the malnourished and nourished patients according to BMI, SGA and NRS 2002, regardless of confounding factors (age and gender), only BMI was associated with HGS, that is, the mean HGS of the malnourished individuals according to BMI were significantly lower than those of the nourished individuals, which is in agreement with Norman et al. ${ }^{9}$ and Schlüssel et al. ${ }^{11}$. Meanwhile, a study done with hemodialysis patients found that the mean $\mathrm{BMI}$ of patients above and within the tenth percentile for HGS did not differ ${ }^{4}$.

On the other hand, many patients with $\mathrm{BMI} \geq 18.5 \mathrm{~kg} / \mathrm{m}^{2}$ had low HGS, indicating that normal BMI values do not reflect adequate muscle mass ${ }^{27}$. There were only four malnourished women according to BMI.

The absence of an association between HGS and SGA is not confirmed by other studies ${ }^{9,17,23}$ which showed that malnourished patients according to the SGA had lower HGS. Regarding the NRS 2002, Matos et al. ${ }^{30}$ found that malnourished patients also presented lower HGS.

Hence, this study contradicts those that showed that HGS was capable of diagnosing nutritional risk or malnutrition 17,23,24,28. A probable explanation is that HGS values were appropriate for most patients, contrary to the findings of other studies 23,24 .

The limitation of the present study may have been the variety of diseases of the study sample. Additional studies are needed to identify the efficiency of the method as a nutritional parameter, comparing HGS with other nutritional assessment methods in hospitalized patients.

\section{CONCLUSION}

Hand grip strength was associated with BMI but not with the SGA or NRS 2002. Hence, the present results suggest that HGS is not a good indicator of nutritional risk and malnutrition in hospitalized patients.

\section{A CKNOWLEDGMENTS}

We thank the patients and staff of the University Hospital/Universidade Federal de Santa Catarina, and the Programa de Apoio ao Plano de Reestruturação e Expansão das Universidades Federais Coordenação de Aperfeiçoamento de Pessoal de Nível Superior for the scholarship. 
56 | MF GARCIA et al.

\section{CONTRIBUTORS}

MFG helped to analyze and interpret the data. MSM helped to conceive and design the study, and collect and review data. LMF helped to analyze and interpret the data. ABD helped to collect the data. EW helped to conceived and design the study and review the data.

\section{REFERENCES}

1. Davies M. Nutritional screening and assessment in cancer-associated malnutrition. Eur J Oncol Nurs. 2005; 9(Suppl 2):S64-S73. doi:10.1016/j.ejon.2 005.09.005.

2. Barbosa-Silva MCG, Barros AJD. Indications and limitations of the use of subjective global assessment in clinical practice: an update. Curr Opin Clin Nutr Metab Care. 2006; 9(3):263-9. doi: 10.1097/01.mco.0000222109.53665.ed.

3. Beghetto MG, Manna B, Candal A, Mello ED, Polanczyk CA. Triagem nutricional em adultos hospitalizados. Rev Nutr. 2008; 21(5):589-601. doi: 10.1590/S1415-52732008000500011.

4. Leal VO, Stockler-Pinto MB, Farage NE, Aranha LN, Fouque D, Anjos L, et al. Handgrip strength and its dialysis determinants in hemodialysis patients. Nutrition. 2011; 27(11-12):1125-9. doi:10.1016/ j.nut.2010.12.012.

5. Fürstenberg A, Davenport A. Comparison of multifrequency bioelectrical impedance analysis and dual-energy $\mathrm{x}$-ray absorptiometry assessments in outpatient hemodialysis patients. Am J Kidney Dis. 2010; 57(1):123-9. doi:10.1053/j.ajkd.2010.0 5.022 .

6. World Health Organization. Global database on body mass index. Geneva: WHO; 2008 [cited 2012 Jan 29]. Available from: <http://apps.who.int/bmi/ index.jsp>.

7. Detsky AS, McLaughlin JR, Baker JP, Johnston N, Whittaker S, Mendelson RA, et al. What is subjective global assessment of nutritional status? J Parenter Enteral Nutr. 1987; 11:8-13. doi: 10.11 77/014860718701100108.

8. Kondrup J, Alisson SP, Elia M, Vellas B, Plauth M. Educational and clinical practice committee, european society of parenteral and enteral nutrition (ESPEN). ESPEN guidelines for nutrition screening 2002. Clin Nutr. 2003; 22(4):415-21. doi:10.1016/S0 261-5614(03)00098-0.

9. Norman K, Schütz T, Kemps M, Lübkle JH, Lochs $\mathrm{H}$, Pirlich $\mathrm{M}$. The subjective global assessment reliably identifies malnutrition-related muscle disfunction. Clin Nutr. 2005; 24(1):143-50. doi: 10.1016/j.clnu.2004.08.007.

10. Gottschall CBA, Álvares-da-Silva MR, Camargo ACR, Burtett RM, Silveira TR. Avaliação nutricional de pacientes com cirrose pelo vírus da hepatite C: a aplicação da calorimetria indireta. Arq Gastroenterol. 2004; 41(4):220-4. doi:10.1590/ S0004-28032004000400004.

11. Schlüssel MM, Anjos LA, Vasconcellos MT, Kac G. Reference values of handgrip dynamometry of healthy adults: a population-based study. Clin Nutr. 2008; 27(4):601-7. doi: 10.1016/j.clnu.2008.04.0 04.

12. Schlüssel MM, Anjos LA, Kac G. A dinamometria manual e seu uso na avaliação nutricional. Rev Nutr. 2008; 21(2):223-35. doi: 10.1590/S1415-5273 2008000200009.

13. Vilaça KHC, Ferriolli E, Lima NKC, Paula FJA, Marchini JS, Morigitu JC. Força muscular e densidade mineral óssea em idosos eutróficos e desnutridos. Rev Nutr. 2011; 24(6):845-52. doi: 10.1590/ S1415-52732011000600005.

14. World Health Organization. Physical status: the use and interpretation of anthropometry. Geneva: WHO; 1995.

15. Cabral PC, Burgos MGPA, Medeiros AQ, Tenório AKT, Feitoza CCF. Avaliação do estado nutricional de pacientes internados em um hospital universitário. Rev Nutr. 1998; 11(2):125-32. doi: 10.1590/S 1415-52731998000200003.

16. Sena FG, Taddeo EF, Andrade Neto ER, Ferreira MSR, Rolim EG. Estado nutricional de pacientes internados em enfermaria de gastroenterologia. Rev Nutr. 1999; 12(3):233-9. doi: 10.1590/S1415-52 731999000300004.

17. Pham NV, Cox-Reijven PL, Wodzig WK, Greve JW, Soetes PB. SGA and measures for muscle mass and strength in surgical Vietnamese patients. Nutrition. 2007; 23(4):283-91. doi: 10.1016/j.nut.2006.12.0 12

18. Wiroth JB, Filippi J, Schneider SM, Al-Jaouni R, Horvais N, Gavarry O, et al. Muscle performance in patients with Crohn's disease in clinical remission. Inflamm Bowel Dis. 2005; 11(3):296-303. doi: 10.1 097/01.MIB.0000160810.76729.9c

19. Leal VO, Mafra D, Fouque D, Anjos LA. Use of handgrip strength in the assessment of the muscle function of chronic kidney disease patients on dialysis: a systematic review. Nephrol Dial Transplant. 2010; 26(4):1354-60. doi: 10.1093/ndt/gfq487.

20. Karaoz S, Aydin N. Nutritional assessment of patients before gastrointestinal surgery and nurses' approach to this issue. J Clin Nurs. 2008; 17(5): 608-17. doi: 10.1111/j.1365-2702.2007.02002.x. 
21. Cardinal TR, Wazlawik E, Bastos JL, Nakazora LM, Scheunemann L. Standardized phase angle indicates nutritional status in hospitalized preoperative patients. Nutr Res. 2010; 30(9):594-600. doi: 10.10 16/j.nutres.2010.08.009.

22. Beghetto MG, Koglin G, Mello ED. Influence of the assessment method on the prevalence of hospital malnutrition: a comparison between two periods. Nutr Hosp. 2010; 25(5):774-80. doi: 10.3 305/nh.2010.25.5.4511.

23. Álvares-da-Silva MR, Silveira TR. Comparison between handgrip strength, subjective global assessment, and prognostic nutritional index in assessing malnutrition and predicting clinical outcome in cirrhotic outpatients. Nutrition. 2005; 21(2):113-7. doi: 10.1016/j.nut.2004.02.002.

24. Bin CM, Flores C, Álvares-da-Silva MR, Francesconi CF. Comparison between handgrip strength, subjective global assessment, anthropometry, and biochemical markers in assessing nutritional status of patients with Crohn's disease in clinical remission. Dig Dis Sci. 2010; 55(1):137-44. doi: 10.1007/s106 20-008-0692-1.

25. Scheunemann L, Wazlawik E, Bastos JL, Cardinal TR, Nakazora LM. Agreement and association between the phase angle and parameters of nutritional status assessment in surgical patients.
Nutr Hosp. 2011; 26(3):480-7. doi: 10.3305/nh.2 011.26.3.4816.

26. Vidal A, Iglesias MAJ, Pertega S, Ayúcar A, Vidal $O$. Prevalence of malnutrition in medical and surgical wards of a university hospital. Nutr Hosp. 2008; 23(3):263-7.

27. Anjos LA. Índice de massa corporal (massa corporal.estatura-2) como indicador do estado nutricional de adultos: revisão da literatura. Rev Saúde Pública. 1992; 26(6):431-6.

28. Pieterse S, Manandhar M, Ismail S. The association between nutritional status and handgrip strength in older Rwandan refugees. Eur J Clin Nutr. 2002; 56(10):933-9. doi:10.1038/sj.ejcn. 1601443.

29. Humphreys J, De La Maza P, Hirsch S, Barrera G, Gattas V, Bunout D. Muscle strength as a predictor of loss of functional status in hospitalized patients. Nutrition. 2002; 18:616-20. doi: 10.1016/S0899-9 007(02)00756-6.

30. Matos LC, Tavares MM, Amaral TF. Handgrip strength as a hospital admission nutritional risk screening method. Eur J Clin Nutr. 2007; 61(9): 1128-35. doi:10.1038/sj.ejcn.1602627.

Received on: 12/4/2012

Final version on: 5/7/2012 Approved on: 20/8/2012 
